\title{
POGODOWE UWARUNKOWANIA DZIAŁAŃ WOJENNYCH. WPŁYW WARUNKÓW ATMOSFERYCZNYCH NA PRZEBIEG STARĆ I KAMPANII MILITARNYCH W OKRESIE ŚREDNIOWIECZA. WYBRANE PRZYKŁADY
}

$\mathrm{K}$

limat i poszczególne zjawiska atmosferyczne nierzadko wywierały znaczący wpływ na działania wojenne, niekiedy przesądzając nawet Nieprzewidywalność czynnika pogodowego sprawia, że nie da się wystarczająco zabezpieczyć przed ewentualnymi szkodliwymi skutkami wystąpienia różnych zjawisk atmosferycznych. Carl von Clausewitz w swoim dziele $O$ wojnie posłużył się metaforą mgły na określenie niepewności będącej nieodłącznym czynnikiem nawet najlepiej zaplanowanych akcji: „Wojna jest dziedziną niepewności; trzy czwarte tego, na czym są oparte działania wojenne, pokrywa mgła większej lub mniejszej niepewności”' Niniejszy artykuł omawia niektóre udokumentowane przykłady sytuacji, gdy sukces lub porażka działań militarnych były w znacznym stopniu uzależnione od panujących warunków meteorologicznych.

Najczęściej wymienianymi w kronikach czynnikami pogodowymi są deszcze, upał lub zimno. Jednak w zdobyciu przewagi nad przeciwnikiem niebagatelną rolę ogrywało również światło słoneczne. W 634 r. Oswald, król Nortumbrii, podstępnie zaatakował Cadwalona z Gwynned o poranku, korzystając z tego, że słońce świeciło prosto w oczy przeciwnika, oślepiając go. Miało to decydujące znaczenie

${ }^{1}$ C. von Clausewitz, O wojnie, t. I, tłum. A. Cichowicz, L. Koc, Warszawa 1958, s. 53; D. Petriello, Tide of War. The Impact of Weather on Warfare, New York 2018, s. 186. 
dla wyniku bitwy, ponieważ Walijczycy nie widzieli, co się dzieje i zostali bez trudu pokonani. Ten sam sposób osłabienia przeciwnika wykorzystał w $687 \mathrm{r}$. Pepin z Heristalu, ojciec Karola Młota, w bitwie pod Tertry². Z kolei Ludwik Pobożny, syn Karola Wielkiego, zmarł z przerażenia kilka dni po tym, jak był świadkiem zaćmienia słońca w maju 840 r. Zjawisko to pośrednio przyczyniło się do podpisania traktatu w Verdun, kończącego wojnę domową, która była następstwem śmierci Ludwika3 .

Nieoczekiwany wiatr przyczynił się w dużej mierze do klęski morskiej wyprawy Rusinów dowodzonych przez Włodzimierza, syna Jarosława Mądrego na Konstantynopol w 1043 r. Wedle Kroniki, czyli historii jednego stulecia Bizancjum (976-1077) autorstwa Michała Psellosa:

\begin{abstract}
Nasi obrzucali ich z góry kamieniami, zwalczali przy pomocy mieczów. Kiedy zaczęto miotać na nich ogniem, pomieszało się im w oczach i albo rzucali się do morza, by wpław dotrzeć do swoich, albo nie wiedzieli, co robić, i rezygnowali z jakiejkolwiek możliwości ratunku. Następnie pada drugi rozkaz dla żołnierzy: wiele trier odbija od brzegu, inne statki płyną za nimi lub prą naprzód [...]. I oto nagle słońce zasnuło się z dołu chmurą, jakby morze podniosło się nad większą częścią horyzontu. Zmieniła się pogoda, spowodował jakiś gwałtowny wiatr dmący ze wschodu na zachód [...]. Bił [wiatr - uzup. A.N.] falami w barbarzyńców, jedne łodzie zatopił na miejscu rzucając na nie wzburzone, rozhuśtane morze, inne długo pędził po morzu i rozbijał o rafy [...]. Triery rzuciły się w pościg za łodziami, jedne pogrążyły w głębiach wraz z załogami, drugie żołnierze, którzy dostali się na nie, rozbijali
\end{abstract}

Przedstawione wydarzenia, które przeszły do historii jako bitwa pod Iskretos z 1043 r. definitywnie zakończyły wojny Rusi Kijowskiej z Bizancjum. O ostatecznym sukcesie cesarskiej floty, obok zastosowania przez załogę tzw. ognia greckiego, zadecydował silny wiatr, który rozbił wiele ruskich łodzi ${ }^{5}$.

Latem 1066 r. Wilhelm Zdobywca zgromadził wojsko do najazdu na Anglię. Pomimo tego, że flota była gotowa na początku sierpnia, z powodu silnych wiatrów musiała zawrócić i mogła wyruszyć dopiero pod koniec września. Wilhelm z Malmesbury odnotował, że gdy z powodu wiatru musieli zawrócić do Saint-Valery-sur-Somme, Wilhelm rozkazał przynieść relikwie św. Walerego i przez dwa tygodnie odmawiać modlitwy błagalne, po czym wiatr nagle ucichł ${ }^{6}$. Harold

${ }^{2}$ G. Halsall, Warfare and society in the barbarian West, 450-900, London 2003, s. 188.

3 D. Petriello, op. cit., s. 23.

${ }^{4}$ Micha£ Psellos, Kronika, czyli historia jednego stulecia Bizancjum (976-1077), tłum. i oprac. O. JuREwiCZ, Wrocław 1985, s. 114.

${ }^{5}$ Vide: В.Г. БрюсовА, Русско-византийские отнотения середины ХІ века, „Вопросы истории" 1972, nr 3, s. 51 i n.

${ }^{6}$ L. Musset, The Bayeux Tapestry, Woodbridge 2005, s. 33. 
z kolei, trzymając wojsko w pogotowiu przez całe lato na południu Anglii, na początku września przemieścił się na północ, a następnie (pod koniec września) musiał stawić czoła norweskim najeźdźcom pod Stamford Bridge ${ }^{7}$, gdzie odniósł zwycięstwo, ale był znacznie osłabiony w momencie pojawienia się Wilhelma i ostatecznie poniósł klęskę pod Hastings.

Wspomniana porażka Norwegów pod Stamford Bridge (1066) była po części skutkiem wysokiej temperatury powietrza - do zwycięstwa Harolda miał się przyczynić fakt, że ciepły wrzesień okazał się zbyt gorący dla Skandynawów, którzy zdjęli zbroje w poszukiwaniu ochłody ${ }^{8}$. Nie spodziewali się ataku, zakładając, że Harold znajduje się o wiele dalej. Upał połączony z brakiem informacji o położeniu anglosaskich wojsk (król Hardrada lekkomyślnie wyruszył z częścią słabo uzbrojonego wojska, nie wysyłając nawet zwiadowców) sprawił, że Wikingowie nie byli przygotowani do walki, a zaatakowani z zaskoczenia nie potrafili wystarczająco skutecznie się bronić ${ }^{9}$.

Co więcej, w marcu tego samego roku na niebie pojawiła się kometa Halleya z płomiennie czerwonym warkoczem, co w kontekście późniejszych wydarzeń zinterpretowano jako zapowiedź klęski Anglosasów. Wilhelm Zdobywca z kolei wykorzystał zjawisko w celach propagandowych, usiłując zdyskredytować swego rywala i poprzeć własne roszczenia. Kometa została przedstawiona na jednej z początkowych scen tkaniny z Bayeux. Jest to prawdopodobnie najwcześniejsze jej przedstawienie zachowane do dnia dzisiejszego ${ }^{10}$.

Pogoda odegrała istotną rolę w dziejach wypraw krzyżowych. Oprócz trudności związanych z zaopatrzeniem i poruszaniem się po nieznanym terenie wśród ataków nieprzyjaciół, niezwykle wysokie (czy też niskie) temperatury lub ulewne deszcze powodowały znaczne osłabienie, choroby oraz rozluźnienie dyscypliny. Wysokie temperatury były pod pewnymi względami jeszcze bardziej niebezpieczne od zimna i deszczu, gdyż często bywały powodem zasłabnięć żołnierzy. Z powodu udaru cieplnego będącego następstwem upału ginęło wielu zbrojnych, szczególnie tych z chłodniejszych krajów, nieprzyzwyczajonych do upalnego klimatu¹1.

${ }^{7}$ Niesprzyjający Wilhelmowi wiatr miał ustać dwa dni po tej bitwie, co dawało mu znaczną przewagę, ponieważ wylądował ze świeżymi siłami wtedy, gdy wojsko Harolda było wyczerpane walką z Norwegami. Vide: D.C. Douglas, William the Conqueror: the Norman impact upon England, London 1964, s. 1035 i n.

${ }^{8}$ Snorri STURLUSON, autor staronordyckiego zbioru sag Heimskringla, napisał, że pogoda była wyjątkowo ciepła, świeciło słońce, zbrojni zatem zeszli na brzeg, zostawiając zbroje na statkach i biorąc jedynie hełmy, włócznie i tarcze, niektórzy z nich mieli również łuki. Zachowywali się bardzo beztrosko. Vide: H.H. Wood, The Battle of Hastings: The Fall of Anglo-Saxon England, London 2008.

${ }^{9}$ D. Petriello, op. cit., s. 127.

10 P. Zumthor, Wilhelm Zdobywca, tłum. E. BĄкоwska, Warszawa 1994, s. 227-228; D. PeTRIELLO, op. cit., s. 11.

${ }^{11}$ Udar cieplny był udziałem wielu krzyżowców, nieprzyzwyczajonych do pustynnego klimatu (vide: S.J. Allen, An Introduction to the Crusades, Toronto 2017). Powodem nagłej śmierci Fryderyka 
Uczestnicy I wyprawy krzyżowej (1096-1099) wiele wycierpieli z powodu upału w trakcie przemarszu przez Anatolię. Ludzie i zwierzęta byli bardzo osłabieni przez brak wody, konie padały i ludzie musieli iść pieszo. Podobnie w $1101 \mathrm{r}$. wysoka temperatura okazała się wielkim wyzwaniem dla krzyżowców zmierzających przez Azję Mniejszą do Syrii. Gdy po wielu trudach część z nich dotarła do Heraklei, byli tak spragnieni, że na widok wody zupełnie zapomnieli o dyscyplinie i rzucili się do picia, co natychmiast wykorzystali seldżuccy Turcy, bez trudu pokonując rozproszone oddziały ${ }^{12}$.

Opisując przemarsz Baldwina I z Edessy do Jerozolimy zimą 1099-1100, Fulcher $\mathrm{z}$ Chartres ${ }^{13}$ wspomina o zimnie i deszczach, które znacznie utrudniały podróż: „często męczył nas dojmujący chłód i ulewne deszcze, a ciepło słońca nie było wystarczające by osuszyć mokre ubrania, gdy deszcz padał nieprzerwanie przez 4 lub 5 dni. Widziałem wielu ludzi, pozbawionych namiotów, których zabiły te zimne deszcze"14. Na skutek tej pogody ucierpieli nie tylko ludzie - padło również wiele zwierząt.

W 1187 r. Gwidon de Lusignan, król Jerozolimy, opuścił dobrze zaopatrzoną w wodę i paszę Seforię, próbując ratować Tyberiadę, celowo zaatakowaną przez Saladyna, aby wywabić krzyżowców z bezpiecznego miejsca na pustynię. Saladyn miał przewagę liczebną ${ }^{15}$, ponadto dzięki zastosowanemu manewrowi armia chrześcijańska znalazła się w potrzasku między oddziałami wojsk muzułmańskich, w silnym upale i bez dostępu do wody. Saladyn dodatkowo kazał rozpalić ogniska, podpalając suchą trawę wokół chrześcijańskiego obozu, żeby jeszcze bardziej osłabić przeciwnika ${ }^{16}$. Kilkudniowy pobyt na pustyni z pewnością miał związek z faktem, że bitwa pod Hittin zakończyła się druzgocącą klęską krzyżowców

Barbarossy w 1190 r. był upadek z konia do zimnej rzeki - różnica temperatur okazała się fatalna (J. Reston Jr., Warriors of God: Richard the Lionheart and Saladin in the Third Crusade, New York 2001, s. 129). Jednak z powodu ciężkiej zbroi każdy rycerz był potencjalnie narażony na przegrzanie organizmu: książę Yorku zginął na skutek udaru cieplnego w bitwie pod Agincourt: E. ОАкеshotT, A Knight and his Armour, London 1961, s. 26.

${ }^{12}$ J. Preiser-Kapeller, A Climate for Crusades? Weather, climate and armed pilgrimage to the Holy Land (1 $11^{\text {th }}-14^{\text {th }}$ Century), 2013, http://oeaw.academia.edu/JohannesPreiserKapeller, s. 1.

${ }_{13}$ Uczestnik I krucjaty, kapelan Baldwina z Boulogne.

14 Fulcher of Chartres, A History of the Expedition to Jerusalem, 1095-1127, New York 1973, s. 131.

${ }^{15}$ Wedle źródeł była to największa armia, jaka zebrała się pod wodzą Saladyna. G. SchlumBerger, Renald z Châtillon. Książę Antiochii. Senior Łacińskiej Zajordanii, tłum. K. Polejowski, Oświęcim 2016, s. 157.

${ }^{16}$ The Conquest of Jerusalem and the Third Crusade: Sources in Translations, P.W. Edbury (ed.), Aldershot 1996, s. 45. Na ten temat vide: J. France, Sztuka wojenna Europy zachodniej w epoce krucjat 1000-1300, tłum. G. SMóŁKA, Oświęcim 2012, s. 268-270. W celu podsycania ognia przez całą noc sucha trawa była dostarczana w okolice obozu chrześcijan. Vide: G. Schlumberger, Renald $z$ Châtillon, s. 168. 
i utratą Jerozolimy ${ }^{17}$. Ryszard I wyciągnął wnioski z tej sytuacji i gdy 4 lata później ruszył w kierunku Jerozolimy z zamiarem ponownego jej zdobycia, zawsze trzymał się wybrzeża i unikał marszu w gorętszych porach dnia ${ }^{18}$.

Pogoda miała wpływ na zakończenie III wyprawy krzyżowej rozejmem na mocy podpisanego w Jaffie traktatu (1192). Pod koniec 1191 r. wojsko Ryszarda I spędziło 6 tygodni w Ramli, gdzie dokuczała im zła pogoda i rajdy przeciwnika. W grudniu wyruszyli w kierunku Jerozolimy, ale gdy dotarli do Betenoble (Beit Nuba), zaskoczyła ich burza gradowa. Na skutek ulewnych deszczy jedzenie się psuło, konie padały, a ludzie chorowali. Autor Itinerarium peregrinorum napisał, że w połowie stycznia ludzie byli wykończeni chorobami i zmęczeniem, niektórzy z nich przeklinali dzień, w którym przyszli na świat i prawie stracili wiarę. Widząc, co się dzieje, Ryszard I zarządził odwrót do Ramli. Ulewne deszcze i grad powstrzymały go przed kontynuacją prób odzyskania Jerozolimy ${ }^{19}$. Pomimo spektakularnego zwycięstwa pod Jaffą w sierpniu 1192 r. krzyżowcy zgodzili się na rozejm, do czego prawdopodobnie przyczyniła się również choroba Ryszarda ${ }^{20}$.

W październiku 1192 r., w trakcie powrotu Ryszarda I z III krucjaty, silny wiatr $\mathrm{z}$ deszczem dwukrotnie znosił statki ${ }^{21}$, zmuszając władcę do zatrzymania się na Korfu i ostatecznie wyrzucając jego statek w okolicach Akwilei. Z braku innych możliwości wyruszył lądem w kierunku Saksonii (gdzie liczył na wsparcie swego szwagra, księcia Saksonii i Bawarii Henryka Lwa). Podróżując w przebraniu, został jednak zauważony przez szpiegów cesarza Henryka VI i wzięty

17 R.C. SmaIL, Sztuka wojenna krzyżowców 1097-1193, tłum. G. Smó£Ka, Oświęcim 2013, s. $179-185$.

18 D. Petriello, op. cit., s. 170.

19 J.E. Philips, The Experience of Sickness and Health During Crusader Campaigns to the Eastern Mediterranean, 1095-1274, PhD Dissertation, University of Leeds 2017, s. 40.

${ }^{20}$ Itinerary of Richard I and others to the Holy Land (formerly ascribed to Geoffrey de Vinsauf), Cambridge, trans. anon., Ontario 2001, s. 204. Vide: The Chronicle of the Third Crusade: The Itinerarium Peregrinorum et Gesta Regis Ricardi, ed. H.J. Nicholson, Aldershot 1997.

${ }^{21}$ Kodeks Siete Partidas, uznawany za najważniejszy zbiór praw w średniowieczu oraz najobszerniejszą kompilację ustawodawczą od czasów Imperium Rzymskiego autorstwa Alfonsa X (1221-1284), króla Kastylii i Leonu wskazuje ogromne znaczenie żywiołu (woda i wiatr) dla prowadzących działania wojenne na morzu: „Biorący udział w działaniach wojennych na lądzie wykazują wielką odwagę, ale odwaga tych, którzy walczą na morzu jest jeszcze większa, ponieważ gdy wojna toczy się na lądzie, zagrożenie stanowi jedynie nieprzyjaciel, ale w sytuacji wojny na morzu dochodzi do tego jeszcze zagrożenie ze strony żywiołu - wody i wiatru. Ten, kto spadnie z konia, nie może upaść niżej niż na ziemię, a zbroja, którą ma na sobie, złagodzi upadek, kto zaś wypadnie ze statku, spadnie aż na dno morza, a ciężka zbroja tylko mu zaszkodzi. Kiedy zbrojni atakują miasto lub zamek na lądzie, mogą się przemieszczać w zależności od sytuacji, lecz na morzu, gdy statki walczą, nie ma możliwości udania się w inne miejsce, zbrojni muszą pozostać na statku otoczonym wodą, narażonym na wiatr i sztorm, i walczyć z całych sił, zdani jedynie na siebie”. Vide: Las Siete Partidas, ed. R.I. Burns, trans. S.P. Sсотт, Philadelphia 2001, Tytuł XXIV, prawo 10, s. 468. 
do niewoli przez księcia Austrii Leopolda V, co miało niebagatelne konsekwencje finansowe i polityczne ${ }^{22}$.

Warunki pogodowe zwykle miały wpływ na sytuację zdrowotną uczestników krucjat. Deszcz niszczył namioty (mokre gniły i rozpadały się), a bez nich ludzie nie mieli schronienia przed zimnem i chorowali jeszcze bardziej ${ }^{23}$. Niektórzy kronikarze odnotowali zależność pomiędzy długotrwałymi deszczami a rozwojem epidemii w czasie oblężenia Antiochii (1097-1098), Akry (1189-1191) i Damietty (1218-1219). Zachorowali Boemund i Rajmund z Tuluzy, a biskup Ademar z Monteil, papieski legat i jeden z dowódców pierwszej krucjaty, zmarł na skutek epidemii wkrótce po zdobyciu Antiochii, co miało negatywny wpływ na los całego przedsięwzięcia $^{24}$. Ambroży z Normandii przypisuje wzrost zachorowań w obozie oblegających Akkę krzyżowców niespotykanym ulewom, przez które niemal się utopili, ale również nie mieli prowiantu i chorowali z głodu lub zepsutego jedzenia, braku wody i nadmiaru wina ${ }^{25}$. Z kolei powódź pod Damiettą zrujnowała trzy statki krzyżowców i spowodowała zniszczenie zapasów żywności, a później na skutek zimna i deszczu wielu uczestników krucjaty zachorowało i zmarło ${ }^{26}$.

Również susza sprzyjała chorobom - spragnieni ludzie często pili wodę ze starych zbiorników, brudną, pełną chorobotwórczych drobnoustrojów. Dyzenteria niszczyła całe armie. Susza powodowała również brak urodzaju, co z kolei pociągało za sobą głód. Na skutek suszy ginęły też zwierzęta, a brak wierzchowców zmniejszał militarny potencjał. Ogromne cierpienie będące wynikiem niezaspokojonego pragnienia mogło popychać ludzi do desperackich czynów, np. zdrady. Guibert z Nogent opisuje jak Rainald, jeden z dowódców, zawarł układ z Turkami, obiecując wydać im własnych żołnierzy. Niektórzy przeszli razem z nim na stronę wroga, inni odmówili i zostali ścięci, ponieważ nie chcieli wyrzec się wiary ${ }^{27}$.

22 J. Gillingham, The Kidnapped King: Richard I in Germany, 1192-1194, „German Historical Institute London Bulletin” 2008, vol. 30, no. 1, s. 5-34; IDEM, Coeur de Lion in Captivity, „Quaestiones Medii Aevi Novae" 2013, vol. 18, s. 59-83; J. Аввотт, History of King Richard I of England, New York 2009, s. 312-317; D. Petriello, op. cit., s. 91.

${ }^{23}$ The First Crusade. The Chronicle of Fulcher of Chartres and other source materials, ed. E. PETERS, second edition, Philadelphia 1998, s. 73.

${ }^{24} \mathrm{O}$ epidemii będącej powodem jego śmierci pisze Albert z Akwizgranu: AlberT of AACHen, Historia Ierosolimitana: History of the Journey to Jerusalem, ed. and trans. by S. B. EdgInGton, Oxford 2007, s. 342.

${ }^{25}$ The History of the Holy War: Ambroise's 'Estoire de la guerre sainte', ed. and trans. by M. Ailes and M. BARBER, 2 vols, Woodbridge 2003. W myśl ówczesnej wiedzy medycznej wino należało pić rozcieńczone, bo w takiej postaci miało pozytywny wpływ, nierozcieńczone z kolei było szkodliwe. Upał i picie nierozcieńczonego wina $\mathrm{z}$ braku wody powodowały choroby i śmierć w czasie V krucjaty. J.E. Philips, op. cit., s. 192.

${ }^{26}$ Oliver z Paderborn w kronice Gesta obsidionis Damiate napisał, że „sexta pars exercitus mortua est". Vide: A History of the Crusades, vol. II, The Later Crusades 1189-1311, eds. K.M. SETton, R. Lee Wolff, H.W. Hazard, Wisconsin 2006, s. 406; J.E. Philips, op. cit., s. 188.

${ }^{27}$ C. Gustafsson, Nature During the Crusades. Physical and Psychological Affects from the Environment in Crusader Narratives, BA Thesis, Luleå Tekniska Universitet 2017, s. 17. 
Mróz, podobnie jak upał, poza ogólnym dyskomfortem powoduje problemy zdrowotne, utrudnione poruszanie się, a nawet śmierć. $Z$ drugiej strony, zamarznięte rzeki niekiedy stwarzały dodatkowe możliwości. W 1142 r. cesarzowa Matylda mogła uciec z obleganego przez jej rywala Stefana z Blois zamku w Oxfordzie właśnie dzięki częściowo zamarzniętej rzece. W ten sposób Stefan utracił szansę na definitywne zakończenie rywalizacji i okres wojny domowej, tzw. Anarchii, trwał do 1154 r., kiedy to rządy objął syn Matyldy, Henryk II ${ }^{28}$.

W Europie Zachodniej (Francja) z reguły unikano angażowania się w działania militarne zimą ${ }^{29}$, m.in. dlatego, że zamarznięta ziemia uniemożliwiała kopanie (okopy, fortyfikacje). Również niechętnie podczas krucjat prowadzono działania zbrojnie w okresie zimowym ${ }^{30}$. Podobnie było też w Polsce ${ }^{31}$. Mongolscy wojownicy potrafili jednak zrobić użytek $\mathrm{z}$ tego, co dla innych stanowiło przeszkodę - twarda, zamarznięta ziemia pozwalała im na szybkie pokonywanie ogromnych odległości. Najazd Czyngis-chana na Chiny w 1211 r. doszedł do skutku głównie dzięki temu, że zamarzły moczary, które w normalnych warunkach były nie do przejścia. Z kolei w 1241 r. Batu-chan zdobył węgierskie miasto Ostrzyhom dzięki temu, że przejechał ze swoją jazdą przez zamarznięty Dunaj ${ }^{32}$. Podobnie, w trakcie inwazji na Polskę w tym samym roku, chan złupił miasto Sandomierz „[...] dokąd mu rzeki Bug i Wisła wtedy zamarzłe nie broniły po lodzie wstępu”33. Również

28 J. Bradbury, Stephen and Matilda. The Civil War of 1139-1153, Stroud 1996.

${ }^{29} \mathrm{~Np}$. żadna z bitew wojny stuletniej nie została stoczona w okresie zimowym (listopad-luty).

30 „Sezon na prowadzenie działań wojennych zwykle ograniczony był do wiosny i lata, a spędzanie zimy w rozmoczonych namiotach i błotnistych okopach nie było atrakcyjną perspektywą". Cf. H. Kennedy, Zamki Krzyżowców, tłum. K. ZıóŁKowski, Oświęcim 2017, s. 131. Trudne warunki pogodowe nie przeszkodziły Saladynowi na udane oblężenie Saphet zimą z 1188 na 1189 r. Do takiej decyzji skłoniła go bardziej determinacja co było dowodem jego szczególnego przywiązania do sprawy świętej wojny: „Saphet jest bardzo trudno dostępną, albowiem ziemia wokół niej jest poprzecinana głębokimi wąwozami. Armia otoczyła to miejsce i ustawiła swoje Mangonele [...] deszcz lał jak z cedru i ziemia zmieniła się w bagno, lecz nie wpłynęło to na zamiary sułtana”. Skuteczny atak machin wojennych spowodował decyzję o poddaniu zamku 6 grudnia 1188 r. Cf. H. KENNEDY, op. cit., s. 131-132. W literaturze przedmiotu przyjmuje się, że utrzymanie oblężenia w trakcie zimy było na Bliskim Wschodzie prawie niemożliwe: „Nawet Bajbars, najbardziej zdeterminowany i umiejętny wyraziciel sztuki oblężniczej z epoki krucjat, prowadził kampanie tylko w trakcie odpowiedniego sezonu, wracając na zimę do swej cytadeli w Kairze”. Cf. ibidem, s. 132-133.

31 Długosz potwierdza ogólną niechęć rycerstwa polskiego do działań wojennych po nastaniu jesiennych, zimnych deszczy: „Przeto, mimo że kończyło się już lato i jesień, która na obszarze Polski jest zwykle zimna, wilgotna i dżdżysta, polecono rycerzom ze wszystkich ziem podległych Królestwu Polskiemu ruszyć w pole, choć liczni, niemal wszyscy, utyskiwali na króla z powodu pozwania wojsk nie w porę, bo kazano im dać się na wojnę w tym czasie, kiedy słusznie powinni być odprowadzeni z niego na leże zimowe”. Cf. J. DŁugosz, Roczniki czyli Kroniki sławnego Królestwa Polskiego, ks. 12 (1445-1461), red. J. Wyrozumski, Warszawa 2004, s. 268.

32 D. Petriello, op. cit., s. 138.

33 Vide: J. DŁugosz, Roczniki, ks. 7-8, oprac. D. Turkowska, M. Kowalczyк, tłum J. MruKówna, red. i komentarz K. Pieradzka, Warszawa 1974, s. 10. Vide: S. Krakowski, Polska w walce z najazdami tatarskimi w XIII wieku, Warszawa 1956, s. 188-193. Ostatnio na ten temat T. GIERGIEL, 
ekspansja militarna prowadzona przez zakon krzyżacki na obszarze Prus, Jaćwieży, Żmudzi, Litwy często była organizowana zimą ${ }^{34}$, kiedy skuta mrozem ziemia była odpowiednia do przemieszczania się znacznych ilości wojsk ${ }^{35}$. Niezmiernie rzadko zaś dochodziło do wypraw wiosną i jesienią, z uwagi na wszechobecne błoto i trudne do pokonania mokradła ${ }^{36}$.

Sukces bitwy morskiej pod Sandwich (1217), która okazała się decydująca dla obrony Anglii przed francuską inwazją, był wynikiem umiejętnego wykorzystania warunków pogodowych. O poranku flota francuska wyruszyła z Calais w kierunku Kent, był lekki wiatr i doskonała widoczność. Francuzi płynęli zgodnie z kierunkiem wiatru, w sprzyjających warunkach. Według Historii W. Marshala francuska flota liczyła około 300 okrętów, którymi dowodził Eustachy Mnich, znany najemnik i pirat ${ }^{37}$. Główny statek Francuzów, którym płynął Eustachy oraz

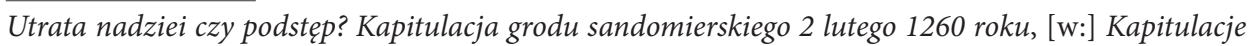
$w$ dziejach wojen. Z dziejów wojskowości polskiej i powszechnej. Seria Homo Militans V, red. A. NIEWIŃsKI, Oświęcim 2017, s. 76-86.

${ }^{34} \mathrm{O}$ wyprawach zbrojnych organizowanych jako zimowe wspomina w swojej kronice Piotr z Dusburga. Vide: Piotr z Dusburga, Kronika ziemi pruskiej, tłum. S. Wyszomirski, wstęp i komentarze J. Wenta, Toruń 2005, s. 190, 201, 203.

${ }_{35}$ Przykładem tego typu wyprawy zimowej jest zorganizowana wielka kampania militarna na Żmudź 1 II 1329 r., w której wojskiem pruskiej gałęzi zakonu niemieckiego dowodził sam wielki mistrz Werner von Orseln, wspierany przez króla Czech Jana Luksemburskiego. Peter von Dusburg, Chronicon terrae Prussiae, wyd. M. Toeppen, [w:] Scriptores Rerum Prussicarum, t. I, Hrsg. T. Hirsch, M. Töppen, E. Strehlke, Leipzig 1861, s. 215; Piotr z Dusburga, Kronika ziemi pruskiej, s. 237; Die Chronik Wigands von Marburg, [w:] Scriptores Rerum Prussicarum, t. II, Hrsg. T. Hirsch, M. TöpPen, E. STRehlke, Leipzig 1863, s. 463; Annales expeditialis Prussici 1233-1414, [w:] Scriptores rerum Prussicarum, t. III, Hrsg. E. StrehlKe, Leipzig 1866, s. 6-12. Na temat tej wyprawy vide: J. Voigt, Geschichte Preussens von den ältesten Zeiten bis zum Untergange der Herrschaft des Deutschen Ordens, Bd. IV: Die Zeit von der Unterwerfung der Preussen 1283 bis zu Dietrich von Altenburg Tod 1341, Königsberg 1830, s. 429-430; W. IWAŃCZAK, Krucjaty Jana Luksemburskiego, [w:] Rycerstwo Europy Środkowo-Wschodniej wobec idei krucjat, red. W. Peltz, J. Dudek, Zielona Góra 2002, s. 115-117; W. Urban, Krzyżacy. Historia działań militarnych, tłum. E. MożEJKo, Warszawa 2007, s. 165-166; M. RaDoch, Walki Zakonu Krzyżackiego o Żmudź od połowy XIII wieku do 1411 roku, Olsztyn 2011, s. 49 . W okresie zimowym również często zdobywano grody, nawet te największe: 22 XII $1391 \mathrm{r}$. wojska zakonne pod dowództwem wielkiego marszałka Engelharda Rabego zdobyły Grodno. O tym fakcie informuje m.in. Wigand, s. 646-647. Vide: M. RADOCH, op. cit., s. 114-115.

${ }^{36} \mathrm{~W}$ tym miejscu warto przytoczyć niezwykle trafne słowa D. Nicolle, autora popularyzatorskiego monograficznego ujęcia bitwy Rusinów z zakonem krzyżackim nad jeziorem Pejpus z 1242 r.: „Rusini, tubylcze ludy z rejonu Bałtyku oraz niemieccy krzyżowcy znad tego morza zwykle prowadzili kampanie w najcięższym okresie zimy, kiedy skuty lodem teren był odpowiedni dla przemieszczania się armii - prawie nie słyszano natomiast o walkach wiosną i jesienią. Były to pory «bezdroży», gdy ziemie poza miastami mogły przemienić się w morze błota, a rzeki, po zapanowaniu odwilży, zostać zablokowane przez niebezpieczne kry lodowe”. Cf. D. Nicolle, Jezioro Pejpus 1242. Bitwa na lodzie, tłum. K. Mróz-Mazur, Oświęcim 2017, s. 62.

37 The History of William Marshal, trans. N. BRyant, Woodbridge 2016, s. 207. Eustachy, młodszy syn hrabiego Boulogne, przez jakiś czas był benedyktynem, stąd przezwisko „Mnich”, lecz później 
36 wysokich rangą rycerzy, z Robertem Courtenay na czele, był ciężki i głęboko zanurzony w wodzie przez to, że transportowano nim machinę oblężniczą oraz konie dla księcia Ludwika ${ }^{38}$. Z tego powodu trudno było nim manewrować.

Dowódca angielskiej floty (o wiele mniej licznej, bo wg Mateusza z Paryża liczącej zaledwie 36 statków) Hubert de Burgh wyruszył im naprzeciw, udając zamiar ataku, ale nie zaatakował i płynął dalej w kierunku Calais. Eustachy pomyślał, że celem Anglików jest Calais i postanowił się nie angażować, jednak Robert Courtenay, który przewyższał go rangą, doszedł do wniosku, że nieliczne angielskie statki płynące pod wiatr stanowią łatwy cel i rozkazał zawrócić i atakować. Wtedy H. de Burgh szybko ustawił się pod wiatr, tyłem do słońca i przejął inicjatywę. Był poranek i słońce świeciło ze wschodu, prosto w oczy Francuzom. Ich okręty były znacznie cięższe od angielskich i nie potrafiły zająć lepszej pozycji, podczas gdy angielscy łucznicy wspomagani przez wiatr wyrządzili nieprzyjacielowi znaczne szkody. Co więcej, Mateusz z Paryża odnotowuje, że Anglicy rzucali niegaszone wapno w proszku, które, niesione przez wiatr, oślepiało Francuzów ${ }^{39}$. Później H. de Burgh wykonał manewr umożliwiający mu atak na francuską ariergardę, gdzie znajdował się okręt E. Mnicha. W wyniku porażki Eustachy został ścięty, a pozostali francuscy rycerze dostali się do niewoli. Ludwik musiał się wycofać i zrezygnować ze swoich roszczeń. Zwycięstwo angielskiej floty było następstwem skutecznego wykorzystania wiatru i słońca oraz zastosowania manewru odwrotu ${ }^{40}$.

W 1262 r. król Norwegii Haakon IV zorganizował wyprawę w obronie Hebrydów i Orkadów, do których rościła sobie prawa Szkocja. Negocjacje przeciągały się (prawdopodobnie było to działanie celowe ze strony czekających na okazję Szkotów), aż jesienią 1263 r. potężny sztorm wyrzucił na brzeg część norweskiej floty i rozproszył pozostałe statki ${ }^{41}$. Podczas gdy Haakon próbował zebrać to, co zostało z jego floty, szkockie wojsko pod dowództwem Aleksandra Stewarta przybyło na Hebrydy. Podzieleni na dwie grupy Norwegowie usiłowali się zjednoczyć, ale wskutek tego opuścili strategicznie bardziej korzystną pozycję na wzgórzu, którą następie zajęli Szkoci. Starcie to, znane jako bitwa pod Largs, zakończyło się wycofaniem Norwegii z Hybrydów ${ }^{42}$.

porzucił zakon, zostając najemnikiem i walcząc najpierw po stronie Anglii a następnie po stronie Francji. Jakkolwiek Roger Wendover nazywa go wielkim niegodziwcem i nikczemnym piratem, był też bardzo kompetentnym marynarzem i dowódcą. Na nieszczęście dla Francuzów, decyzję o ataku podjął wyższy rangą, ale znacznie mniej kompetentny Robert Courtenay.

${ }^{38}$ History of William Marshal..., s. 208.

39 S. Lewis, The Art of Matthew Paris in the Chronica Maiora, California 1987, s. 59.

40 Ch.D. Stanton, Medieval Maritime Warfare, Barnsley 2015, s. 236 i n. Vide: S. Rose, English Medieval Navy 1066-1509: Ships, Men and Warfare, Barnsley 2013.

${ }^{41}$ A. Forte, R. Oram, F. Pedersen, Viking Empires, Cambridge 2005, s. 258-259.

42 D. Petriello, op. cit., s. 92. 
Nieprzewidywalność pogody stanowiła duże utrudnienie, gdy chodzi o zaopatrzenie. Często zapasy żywności wysyłane drogą morską nie docierały na czas, co mogło być powodem poważnych kłopotów. Przykładem tego, jak niepomyślne wiatry omal nie stały się przyczyną katastrofy militarnej, jest opóźnienie dostawy żywności w 1298 r. Kampania Edwarda I mogła zakończyć się całkowitą porażką, ponieważ wskutek braku żywności jego ludzie byli osłabieni i zaczęli chorować. Według kroniki Waltera z Guisborough statki w końcu dotarły z dużym opóźnieniem, ale okazało się, że przywiozły znaczne ilości wina i niewiele żywności. Nadmiar wina z kolei spowodował bunt Walijczyków, którzy nadużyli tego trunku. Król chciał już zarządzić wycofanie się do Edynburga, gdy jego zwiadowcy donieśli o nadejściu Szkotów, którzy chcieli wykorzystać ciężką sytuację przeciwnika. Takie były bezpośrednie okoliczności rozpoczęcia bitwy pod Falkirk, w której Anglicy ostatecznie odnieśli zwycięstwo. Nie byli jednak w stanie, zgodnie z wcześniejszym zamiarem, podporządkować sobie Galloway, ponieważ zaopatrzenie znów nie dotarło na czas ${ }^{43}$.

Deszcz odegrał istotną rolę w wyprawie Edwarda III mającej na celu odparcie szkockich najazdów, znanej jako kampania Weardale w 1327 r. Pomimo że siłom angielskim udało się zdjąć oblężenie Norham, nie były w stanie pokonać Szkotów. Zła pogoda (ciągłe deszcze i dość niskie temperatury) oraz skuteczna taktyka wojny podjazdowej sprawiły, że Anglicy musieli wycofać się i poszukać rozwiązań pokojowych, co ostatecznie poskutkowało podpisaniem traktatu w Edinburgh-Northampton (1328), uznającego suwerenność Szkocji oraz Roberta Bruce’a jako jej prawowitego władcę. Fatalną w skutkach wyprawę opisał jeden z jej uczestników, kronikarz Jean le Bel. Douglas, dowódca Szkotów, obrał taktykę zwodzenia przeciwnika, unikając otwartej konfrontacji, lecz cały czas zachęcając go do podjęcia wyzwania. Jak opisuje J. Le Bel, niewielkie, mobilne oddziały Szkotów pojawiały się i znikały, prowadząc Anglików w zimnie i deszczu przez moczary, lasy, bezdroża, góry i doliny i będąc zawsze o krok do przodu ${ }^{44}$. Dodatkowo teren nie nadawał się dla ciężkiej jazdy i rozbudowanych taborów, dlatego też w pewnym momencie Anglicy musieli je zostawić. Chcąc dogonić Szkotów, rycerze wzięli tylko po bochenku chleba przywiązanego do siodła, ale nadal mieli ciężkie konie i zbroje. Padało bez przerwy przez 9 dni, wskutek czego zepsuły się mizerne porcje żywności (chleb po nasiąknięciu deszczem i końskim potem nie nadawał się do jedzenia) i zardzewiały kolczugi, nie mówiąc już o fizycznym wyczerpaniu uczestników wyprawy ${ }^{45}$. W dodatku wezbrała rzeka, przez którą angielscy rycerzy chcieli się przeprawić, spędzili zatem kilka dni na brzegu rzeki bez prowiantu,

${ }^{43}$ F.J. WATson, Edward I in Scotland 1296-1305, PhD thesis, University of Glasgow 1991, s. 272.

${ }^{44}$ K. DeVRIES, Infantry Warfare in the Early Fourteenth Century. Discipline, Tactics, and Technology, Woodbridge 2006, s. 112.

${ }^{45}$ R. Nicholson, Edward III and the Scots, Oxford 1965, s. 26 i n. 
paszy i dachu nad głową ${ }^{46}$. Nie potrafili zlokalizować nieprzyjaciela ani zmusić go do otwartej walki. Szkoci z kolei zdołali jeszcze zaatakować w nocy angielski obóz i o mało co nie wzięli króla do niewoli (jego ludzie z trudem zdołali odeprzeć atak, wielu z nich zginęło). Po wszystkich poniesionych stratach Edwardowi nie pozostało nic jak tylko wrócić do Yorku, skąd wyruszył ${ }^{47}$.

Deszczowa pogoda miała również istotny wpływ na przebieg bitwy pod Crécy (1346). Gdy Francuzi wyruszyli z Abbeville, rozpoczęła się gwałtowna burza ${ }^{48}$. Nie wiadomo, jak długo padało, ale deszcz był na tyle intensywny, by zamienić ziemię w błoto. Co więcej, intensywna ulewa na początku bitwy zmoczyła kusze genueńskich najemników. Cięciwy straciły elastyczność, a co za tym idzie, zmniejszyła się siła rażenia. Takich problemów nie mieli jednak angielscy łucznicy, ponieważ z nadejściem deszczu szybko zdjęli swoje cięciwy z łuków i schowali pod hełmami ${ }^{49}$ (manewr nie do wykonania w przypadku bardziej skomplikowanego mechanizmu kuszy). Nagła burza zaskoczyła Genueńczyków i jeśli nawet znali jakieś sposoby ochrony kusz przed zalaniem, nie mieli możliwości z nich skorzystaćs0. Gdy pięcio- lub sześciotysięczna formacja kuszników ruszyła do ataku, deszcz mógł się już skończyć, ale mała dolina zamieniła się w błoto, co spowolniło akcję, a przemoknięte kusze nie były wystarczająco skuteczne. Ponadto większość pocisków i pawęże, używane jako osłona przy ładowaniu broni, zostały z tyłu na wozach taborowych. Wielu kuszników miało otwarte hełmy, tylko niektórzy nosili na sobie zbroję. Dodatkową przeszkodą było to, że po zakończeniu burzy słońce świeciło atakującym prosto w oczy, uniemożliwiając skuteczne działanie. Anglicy z kolei, mając słońce $z$ tyłu, doskonale widzieli swój cel ${ }^{51}$. Zważywszy na to, że pod Crécy było co najmniej 5 tysięcy angielskich łuczników, którzy mogli wystrzelić od 6 do 10 strzał na minutę, w kierunku przeciwnika leciało jakieś 30 tys. strzał na minutę ${ }^{52}$.

${ }^{46}$ J. SAdLer, Border Fury. England and Scotland at War 1296-1568, Harlow 2005, s. 112.

47 Ibidem, s. 171.

48 K. DeVries, The Implications of the Anonimo Romano Account of the Battle of Crécy, [w:] The Medieval Way of War. Studies in Medieval Military History in Honor of Bernard S. Bachrach, ed. G.I. HALFOND, London 2015, s. 318-319.

49 Pisze o tym Jean DE Venette: „Suddenly rain descended upon the heaven [...] the strings on the crossbows of the Genoese crossbowmen who had come to aid the French were soaked by the rain and shrank, so that when it was time for them to be drawn against the English, they were, woe is me! useless. It was not so with the bows and arrows of the English, for when the rain began as they were awaiting battle, they had quickly protected their bows by putting the bow strings on their heads under their helmets". The Chronicle of Jean de Venette, trans. J. BirdSALL, New York 1953, s. 43.

${ }^{50}$ K. DeVRIEs, Infantry..., s. 167-169. Vide: R.W. BARBER, Edward III and the Triumph of England. The Battle of Crécy and the Company of the Garter, London 2013.

51 J. Froissart, Chronicles, selected, translated and edited by G. Brereton, London 1978, s. 88; M. Livingstone et al., Road to Crécy. The English Invasion of France, 1346, Abingdon 2005, s. 286 i n.

52 A. Ayton, The English Army at Crécy, [w:] A. Ayton, Sir Ph. Preston, The Battle of Crécy, 1346, Suffolk 2005, s. 159-252; A. Ayton, Ph. Preston, Topography and Archery: Further Reflections on the Battle of Crécy, [w:] ibidem, s. 351-378; I. Montimer, Edward III. The Perfect King, 2014. 
W tej sytuacji już po pierwszej minucie bitwy straty Francuzów musiały być ogromne. Kusznicy (którzy już przed bitwą byli zbyt zmęczeni po ciężkim i długim marszu), widząc że nie mają szans, rzucili się do ucieczki, ale ku ich zaskoczeniu Francuzi zwrócili się przeciwko nim. Myśląc, że ma do czynienia ze zdradą i że kusznicy celowo blokują im drogę, hrabia d'Alençon wydał swoim ludziom rozkaz ataku na Genueńczyków, którzy znaleźli się w pułapce między Anglikami a francuską jazdą, a następnie sam król rozkazał „zabić cały ten tłum, gdyż tylko wchodzą nam w drogę!" 53 , w wyniku czego powstało zamieszanie bardzo korzystne dla Anglików ${ }^{54}$. W ten sposób, pomimo znacznej przewagi liczebnej, Francuzi ponieśli spektakularną porażkę.

Traktat z Bretigny (1360), na mocy którego Edward III miał zrezygnować z roszczeń do francuskiego tronu, postrzegany bywa jako następstwo strasznej burzy, wskutek której wojska Edwarda poniosły znaczne straty. W 1359 r. Edward wylądował w Calais i plądrował okolice, przemieszczając się przez północną Francję. Francuzi unikali otwartego starcia, co pozwoliło Anglikom dotrzeć w okolice Paryża i rozpocząć oblężenie Chartres. 13 kwietnia 1360 r. (był to poniedziałek Wielkanocny, który przeszedł do historii jako Czarny Poniedziałek) rozpętała się gwałtowna burza gradowa z piorunami, której towarzyszył duży spadek temperatury. Burzę opisują m.in. Froissart (który dostrzega tu działanie mocy nadprzyrodzonych), Anonimalle Chronicle i Thomas Gray (Scalacronica) ${ }^{55}$. Według Froissarta grad był ogromnej wielkości i nawet najodważniejsi byli przerażeni, gdyż wydawało się, że nadszedł koniec świata ${ }^{56}$. Wielu ludzi Edwarda zginęło - według Chronicon Henry'ego Knightona były to tysiące zbrojnych i 6 tys. koni $^{57}$ - a samo zjawisko odczytano jako zły omen ${ }^{58}$. Angielski król się wycofał. Trzy tygodnie później podpisano wspomniany traktat w Bretigny.

Jesienią 1415 r. pod Azincourt trwające przez dwa tygodnie ulewne deszcze unieruchomiły francuską ciężką jazdę, która ugrzęzła w błocie, stając się łatwym celem dla angielskich łuczników. Pomimo faktu, że Francuzi mieli przewagę liczebną, a wojsko dowodzone przez Henryka V było wyczerpane chorobami i długim marszem, sytuacja Francuzów okazała się gorsza. Zderzenia i poślizgi praktycznie uniemożliwiły manewrowanie, zaś atak łuczników spotęgował dezorientację. Anonimowy kronikarz z opactwa Saint-Denis odnotował, że rycerze,

53 J. Froissart, op. cit., s. 89.

54 P.J. Geary, Readings in Medieval History, Toronto 2016, s. 686; K. DeVRIEs, op. cit., s. 167-169.

55 D. Nowakowski-Baker, Meed and the Economics of Chivalry in Piers Plowman, [w:] Inscribing the Hundred Years' War in French and English Cultures, ed. D. Nowakowski-Baker, Albany NY 2000, s. 64-66.

56 C. Rogers, The Wars of Edward III. Sources and Interpretations, Woodbridge 1999, s. 182.

57 Chronicon Henrici Knighton vel Knitthon, monachi Leycestrensis, vol. 2, ed. J.R. LumbY, Cambridge 2012, s. 112 .

58 J. SADLER, op. cit., s. 23. 
brnąc po kolana w grzęzawisku, byli przemęczeni już przed rozpoczęciem starcia, dodatkowo przez to, że spędzili bezsenną noc ${ }^{59}$. Żadna z zachowanych kronik nie mówi o deszczu w czasie trwania bitwy, ale większość (np. Gesta Henrici Quinti czy Liber Metricus Thomasa Elmhama) wspomina o deszczu w przededniu bitwy $\mathrm{i} /$ lub w nocy. Thomas Walsingham z kolei nie pisze o deszczu, ale zaznacza, że Anglicy byli osłabieni przez choroby i zimne noce, jak również niedożywieni (brakowało chleba) i zmęczeni przez wyczerpujący marsz, dodając później, że miejsce bitwy było bardzo błotniste ${ }^{60}$. W źródłach francuskich wątek ulewy jest bardziej obecny - Pierre Cochon pisze, że noc była bardzo deszczowa i ziemia rozmiękła tak bardzo, że ludzie grzęźli w błocie na głębokość stopy ${ }^{61}$. Jean le Fèvre de Saint-Remy i Jean de Waurin, którzy byli naocznymi świadkami wydarzeń, lecz opisali je znacznie później, wspominają o lejącym przez całą noc deszczu, który jeszcze bardziej pogorszył i bez tego zły stan gruntu ${ }^{62}$.

Cała seria anomalii pogodowych towarzyszyła końcowej fazie Wojny Róż, przyczyniając się do zwycięstwa stronnictwa Yorków. 2 lutego 1461 r. zjawisko meteorologiczne znane jako parhelion zostało odczytane przez Edwarda, księcia Yorku i przyszłego króla, jako znak przychylności niebios, co dodało animuszu zarówno jemu jak i jego ludziom ${ }^{63}$. Zwycięstwo w bitwie pod Mortimer's Cross, odniesione tego samego dnia, stało się ważnym krokiem w kierunku jego ostatecznego sukcesu, uwieńczonego koronacją na Edwarda IV ${ }^{64}$.

Dla rozegranej 29 marca $1461 \mathrm{r}$. bitwy pod Towton decydujące znaczenie miał mokry, oblepiający śnieg, sypiący prosto $\mathrm{w}$ oczy armii Lancasterów ${ }^{65}$. Uniemożliwiał im dostrzeżenie wroga i odpowiednią ocenę odległości. Strzały ich łuczników były zbyt lekkie, wystrzeliwane dodatkowo pod wiatr trafiały w próżnię (około $45 \mathrm{~m}$ za blisko), nie dosięgając Yorkistów, których z kolei cięższe strzały wystrzeliwane $\mathrm{z}$ wiatrem dziesiątkowały szeregi przeciwnika ${ }^{66}$. Posuwający się do przodu łucznicy Yorkistów zebrali z ziemi tysiące wystrzelonych przez wroga

59 D. Petriello, op. cit., s. 55; A. Curry, The Battle of Agincourt. Sources and Interpretations, Woodbridge 2000, s. 106.

${ }^{60}$ T. Walsingham, St. Albans Chronicle 1406-1420, ed. V.H. Galbraith, Oxford 1937, s. 92-98; A. Curry, op. cit., s. 50 .

${ }^{61} \mathrm{O}$ trudnościach z poruszaniem się w błocie wspominają też inni kronikarze: Jean Juvenal des Ursins, Jean de Waurin, kronikarz z Ruisseauville. Vide: M. Jones, 24 hours at Agincourt, London 2016; A. CURrY, op. cit., s. 113.

${ }^{62}$ A. CURrY, op. cit., s. 135 i n.

${ }^{63}$ Ch.D. Ross, Edward IV, Berkeley-Los Angeles 1974, s. 31-32.

${ }^{64}$ J. SAdLER, Towton. The Battle of Palmsunday Field 1461, Barnsley 2011, s. 61.

${ }^{65} \mathrm{O}$ obfitych opadach śniegu wspominają co najmniej trzy kroniki: Hearn's Fragment of an Old English Chronicle, Croyland Abbey Chronicle i Hall's Chronicle. Cf. A.W. BoArdman, Towton. The Bloodiest Battle, Stroud 2000, s. 128.

${ }^{66}$ Pierwsze minuty bitwy rozpoczynanej przez atak łuczników zwykle decydowały o jej wyniku - strona ponosząca większe straty była dodatkowo zmuszona do zainicjowania walki kontaktowej i zwykle była skazana na klęskę. A.W. Boardman, The Battle of Towton, Stroud 1996, s. 114-117. 
strzał i wypuszczali je ponownie z wiatrem, po czym cofali się, aby uniknąć niecelnych ataków nieprzyjaciela ${ }^{67}$. Ponadto prószący przez kilka poprzedzających bitwę dni śnieg osłabił cięciwy łuków Lancasterskich łuczników. Wilgoć spowodowała również, że sprowadzona z Londynu bombarda stała się bezużyteczna, jak również inny pokaźny rodzaj artylerii, którą dysponował Edward. Zrobiło się też bardzo ślisko, tak że zbrojnym trudno było utrzymać równowagę. Śnieg również spowodował gwałtowne wezbranie okolicznej rzeki, mającej okazać się jedyną a zarazem zgubną drogą ucieczki wojsk Lancasterów, z których część utonęła w lodowatej wodzie ${ }^{68}$. Bitwa była niezwykle krwawa i zacięta. Wedle najbardziej prawdopodobnych szacunków zginęło 40 tys. walczących ${ }^{69}$ i jest rzeczą pewną, że część z nich - będąc rannymi - zmarła w następstwie fatalnych warunków pogodowych ${ }^{70}$.

Warunki pogodowe miały wpływ również na wynik bitwy pod Barnet w kwietniu 1471 r., w zasadzie kończącej Wojnę Dwóch Róż. Rano w dniu bitwy panowała gęsta mgła ${ }^{71}$, wskutek czego obie strony straciły orientację i źle oszacowały położenie przeciwnika ${ }^{72}$. Hrabia Oxford John de Vere początkowo zyskał przewagę, atakując wojsko Yorków od skrzydła, ale później przez pomyłkę zaatakował oddział swego sojusznika lorda Montague. Zamieszanie, które powstało w szeregach Lancasterów (m.in. na skutek pomylenia własnego herbu $\mathrm{z}$ herbem Yorków, tzw. „Słońce w chwale”), umożliwiło Edwardowi wprowadzenie odwodów i zdobycie definitywnego zwycięstwa ${ }^{73}$.

${ }^{67}$ A. WeIr, Lancasterowie i Yorkowie. Wojna Dwóch Róż, tłum. K. KRóLIK, Kraków 2013, s. 323.

${ }^{68}$ D. Petriello, op. cit., s. 115.

${ }^{69}$ A. WeIR, op. cit., s. 325.

${ }^{70}$ W tym miejscu warto przytoczyć słowa Długosza, kiedy to po bitwie grunwaldzkiej, „gdy słońce zaszło, spadł deszcz, a ponieważ przez całą noc padał bez przerwy, w obydwu wojskach, królewskim i pruskim, zginęło od ostrego zimna wielu pozostawionych na polu walki rannych, którzy mogliby byli żyć, gdyby ich stąd zabrano i otoczono opieką". Vide: J. DŁugosz, Roczniki, ks. 10-11, red. K. Pieradzka, Warszawa 1982, s. 138.

${ }^{71}$ J. SADLER, op. cit., s. 23.

${ }^{72}$ O początkach rozegranej 27 IX 1331 r. bitwy pod Płowcami rozstrzygnęła mgła, która sprawiła, że zwłaszcza strona krzyżacka nie miała pełnego rozeznania co do sił i rozmieszczenia strony polskiej. Wystąpienie mgły potwierdzają źródła krzyżackie. Vide: W.M. ks. Luter brunświcki o sprawie Zakonu $z$ Łokietkiem w r. 1331 (List wielkiego mistrza Luthera $z$ Brunszwiku do prokuratora krzyżackiego w Awinionie Teodoryka de Auro Capite), wyd. A. KŁodziński, Miscellanea. Ze studiów krytycznych nad r. 1331, „Kwartalnik Historyczny” 1905, R. XIX, s. 41; Wigand..., s. 481. Panująca mgła mogła stanowić również dla Krzyżaków sytuację dogodną, gdyż umożliwiała im poruszanie się w trudniej zauważalny sposób. Polacy jednak, planując atak, dzięki mgle zyskiwali nadzwyczaj sprzyjające warunki niepostrzeżonego zbliżenia się do przeciwnika. Więcej na ten temat vide: A. NIEwIŃski, Jeńcy spod Płowiec. Niewola militarna i pole bitewne, [w:] Pola bitew wczoraj i dziś, red. A. Olejko, P. Korzeniowski, K. Mroczkowski, Oświęcim 2013, s. 276-286.

${ }^{73}$ D. Petriello, op. cit., s. 73; A. Weir, op. cit., s. 454-457. 
Ulewne deszcze w 1476 r. pośrednio wpłynęły na przebieg bitwy pod Toro, która, pomimo braku wyraźnej przewagi jednej ze stron, okazała się rozstrzygająca w wojnie o sukcesję kastylijską. Alfons V, król Portugalii, prowadził wojsko $\mathrm{z}$ zamiarem zdobycia Zamory $\mathrm{w}$ ramach walki przeciwko Ferdynandowi Aragońskiemu, ale trwający przez wiele dni ulewny deszcz, śnieg i zimno utrudniały wszelkie przygotowania i miały tak demoralizujący wpływ na jego ludzi, że Alfons ostatecznie porzucił swoje roszczenia do kastylijskiego tronu i wyruszył z powrotem do Portugalii. Ferdynand wykorzystał sytuację i zaatakował osłabionego przeciwnika, czego wynikiem była bitwa pod Toro. Mimo że nie dało się stwierdzić definitywnej przewagi żadnej ze stron, Alfons ostatecznie wycofał się z Hiszpanii, a dawni zwolennicy Joanny (córki króla Kastylii Henryka IV i żony Alfonsa) zaczęli popierać Izabelę, przyrodnią siostrę Henryka ${ }^{74}$.

Starannie zaplanowana rebelia Henryka Stafforda, księcia Buckingham, przeciwko Ryszardowi III w 1483 r. została w znacznej mierze udaremniona przez niespodziewane komplikacje pogodowe - burze, ulewę i powódź. Buckingham miał ruszyć na Londyn po przeprawieniu się przez rzekę Severn, której wezbranie udaremniło ten plan. $Z$ tego samego powodu obiecane przez Henryka Tudora wsparcie nie doszło do skutku' ${ }^{75}$.

Zjawiska pogodowe mogły zatem wywrzeć (i niejednokrotnie wywierały) wpływ na przebieg kampanii militarnych i starć bitewnych, których rezultat niekiedy zmieniał bieg historii. Śnieg, burza czy mgła wprowadzały znaczącą dezorganizację po jednej lub obu stronach konfliktu, krzyżując plany walczących. Również temperatura powietrza i jej gwałtowne zmiany odgrywały niemałoważną rolę w toku działań militarnych. W zależności od położenia geograficznego i przyzwyczajenia do określonego klimatu, wzrost lub spadek temperatury mógł być korzystny dla jednej ze stron - np. upał stanowił atut dla przywykłych do wysokich temperatur mieszkańców Bliskiego Wschodu, w odróżnieniu od Europejczyków czy Skandynawów, Krzyżacy czy Mongołowie z kolei preferowali niskie temperatury z uwagi na fakt, że umożliwiało im to sprawne przemieszczanie się po drogach nieprzejezdnych w cieplejszych porach roku. Warunki atmosferyczne mogły utrudniać pieszym i konnym poruszanie się, powodować opóźnienie zaopatrzenia, sprzyjać rozwojowi chorób. Nie zawsze jednak miały charakter decydujący, gdyż zwykle ostateczny wynik tego czy innego konfliktu zbrojnego zależał od całego konglomeratu takich czynników jak błędy dowódców, niewłaściwe

${ }^{74}$ D. Petriello, op. cit., s. 57; Historia general de España y América: Los Trastámara y la unidad española (1369-1517), tomo V, Madrid 1981, s. 487.

${ }^{75}$ C. RawCliffe, The Staffords, Earls of Stafford and Dukes of Buckingham: 1394-1521, Cambridge 1978, s. 33 . 


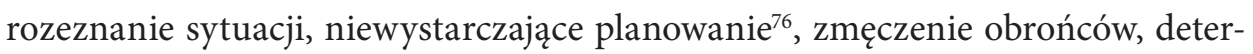
minacja atakujących ${ }^{77}$, jak też zwykły przypadek.

\title{
Andrzej Niewiński \\ WEATHER CONDITIONS OF MILITARY OPERATIONS. THE INFLUENCE OF ATMOSPHERIC CONDITIONS ON THE COURSE OF PITCH BATTLES AND MILITARY CAMPAIGNS IN THE MIDDLE AGES. SELECTED EXAMPLES
}

\begin{abstract}
Summary: The article examines the impact of adverse weather conditions and astronomical occurrences on the outcome of the selected medieval military campaigns and pitch battles. Unpredictability of weather was an important factor in medieval warfare: unexpected wind, rain, snow, heat or day-to-night temperature fluctuations could influence a military operation in a significant way. As medieval chronicles recorded, troops often suffered from famine as a result of excessive rains, droughts or adverse winds which prevented supplies from being delivered by sea. Apart from causing fatigue and exhaustion bad weather contributed to disease outbreaks and equipment damage. People were weakened physically and psychologically which reduced their fighting ability.
\end{abstract}

Keywords: Middle Ages, the war, weather and war, history of warfare.

${ }^{76}$ Krzyżacka wyprawa z udziałem gości rycerzy z Anglii, Francji, Niemiec na Wilno (1390 r.) zakończyła się jedynie połowicznym sukcesem. Wojska zakonne zdobyły tylko drewniany zamek, zaś murowane zamki - Górny i Dolny - mimo niemal pięciotygodniowego oblężenia nie zostały zdobyte, jakkolwiek rycerstwo zakonne niepodzielnie panowało nad okolicą, plądrując teren (nie brakowało więc prowiantu i paszy, dodatkowo dostarczanych przez kupców litewskich i żmudzkich). Dopiero brak prochu i pogarszająca się pogoda skłoniły głównodowodzącego wielkiego marszałka Engelharda Rabego do zaniechania oblężenia i decyzji odwrotu. Vide: M. RADOCH, op. cit., s. 105-109. „I musieli stamtąd wychodzić, dlatego że już późno było w tym roku i przez niestałą pogodę, musieli oni pośpiesznie do kraju powracać, gdyż tam oni chcieli przez wody brodami [przechodzić], kiedy te wody zaczynały się bardzo podnosić, i te drogi złymi się stawały, oni nie mogli dłużej tam pozostawać". Tłum. za M. RADoch, op. cit., s. 109, przyp. 640.

77 Swoistym testem wytrzymałości na warunki pogodowe było oblężenie przez Saladyna (w okresie zimowym) zamku Belvoir należącym do krzyżowców: „Mury (zamku), zbudowane z kamienia i gliny, zapewniały doskonałą ochronę będącym za nimi, przez co nikt nie mógł wyjść przez namiot nie założywszy na siebie pancerza. Deszcz padał nieustannie, a błoto było tak gęste, że poruszanie się pieszo czy konno było niemożliwe. Cierpieliśmy strasznie z powodu wichrów i silnego deszczu, jak również z powodu bliskości nieprzyjaciela, który ze swojej pozycji, dominował nad naszą armią, zabijając i raniąc wielką liczbę ludzi”. Cyt. za: H. Kennedy, Zamki Krzyżowców..., s. 132. O ostatecznym sukcesie atakujących zdecydowało mimo wszystko pozostanie i uporczywe obleganie twierdzy, podkop i zawalenie się części murów. Cf. ibidem. 